\title{
POLITICAL SLOGANS: CORE CHARACTERISTICS AND SPECIFICITY
}

\author{
Anastasia Kovalevska \\ $\mathrm{PhD}$ in Philology (Ukrainian Language), Associate Professor at the Department of Ukrainian \\ and Foreign Languages, Odessa Regional Institute for Public Administration \\ of the National Academy for Public Administration under the President of Ukraine, Ukraine \\ e-mail: ana.kovalevskaya@gmail.com,orcid.org/0000-0002-1031-5546
}

\begin{abstract}
Summary
The article is dedicated highlighting the peculiarities of the political slogan as one of the basic advertisement campaign components which embodies the total pool of the ideas of the whole advertisement campaign. and outlining the general, special and influential peculiarities of the political slogan as a potentially influential text, because of immanent suggesogeneousness being its functional characteristic. The particular specific differences of a political slogan from a commercial one according such characteristics as continuity and frequency of operation, specificity, differentiation, and audience coverage are outlined, temporal limitation of the political advertisement due to the fact that the political advertisement's validity is regulated legislatively, especially emphasized. The linguistic characteristics of political slogans, being an element of a larger political texts array, are highlighted, and the general recommendations as to how to reach top efficiency of a political slogan are provided, including one concerning taking the mental characteristics of the potential recipients into account when formulating the political campaign, slogan being its core element.
\end{abstract}

Keywords: political advertisement, political slogan, suggestion, Neurolinguistic Programming, Suggestive Linguistics, media, state information policy.

DOI: https://doi.org/10.23856/4006

\section{Introduction}

As M. Ozhevan notes, "language is inseparable from politics and governmental decisions, and only in this context can it become adequately understood" (Ozhevan), so, "in the 21 st century it is important to use innovative methods and teaching aids" (Yassin, 2020: 120) utilizing the suggestion techniques in the sphere of politics and public management is extremely crucial not only in order to analyze the political texts, but to optimize the very construction of these texts considering the according brand new scientific technologies, as well, what defines the relevance of this work.

\section{Setting the problem and its connection with important tasks}

The article is aimed at highlighting the peculiarities of the political slogan as one of the basic advertisement campaign components. In order to achieve this aim, it is necessary to find solutions to the following specific tasks: outline the general, special and influential peculiarities of the political slogan as a potentially influential text. The political slogan as the structural component of the political advertisement campaign is the object of our research, while its immanent linguistic peculiarities are the subject. 
Ch. Wright emphasizes that the mass communication is directed towards the large and heterogeneous audiences, which are anonymous concerning the communicator oneself (Kovalevska, 2001), and in its network, the messages are transmitted extremely quickly, in order to reach as large an audience as possible, and usually at once, advertisement being one of the most wide-spread and omnipresent textual arrays within the whole information sphere, slogan being its very center and defining the whole essence of the campaign with several words, which have to be chosen carefully enough to actually reflect thousands, because of immanent suggesogeneousness being its functional characteristic and thus extremely closely related to the language (Shamsollahi, Amirshahi, Ghaffari, 2017).

\section{General peculiarities of political slogans}

Alongside with the commercial and social slogans, the researchers isolate the political slogans, which contain the basic message of the political campaigns, are the "verbal portrait of the political figure" (Morozova, 1996: 5), "statement that reflects the candidate's precise position" (Cherepanova, 2002: 307). Political advertisement basically relies on "the human's unconscious desire to compensate the lost symbolism of one's correlation with the world of things" (Pocheptsov, 2001: 113), and attempts "with the help of signs, to fill the void the psyche protests against" (Pocheptsov, 2001: 113). The main objective of any slogan, be it a political, a commercial, or a social advertisement one, is to make the recipient purchase goods or services, regardless of whether the recipient actually needs these goods or services or not, also manifesting in "assigning a commercially relevant name" (Tepla, 2012: 192). It is a part of the advertisement campaign of, since the slogan is "an essence of the advertisement campaign compressed to a formula, rememberable thought brought to linguistic perfection" (Feofanov, 2003: 225). The political slogan does meet this definition, but also has its own specific properties, which are connected with the specificity of the political campaign comparing to a commercial one. The political slogan has particular differences from a commercial one according to the following characteristics:

1. Continuity and frequency of operation. The political advertisement's validity is regulated legislatively, with the help of the Law of Ukraine "On Elections", and such advertisement ends after the political leader has been elected. On the contrary, the commercial advertisement is active constantly, with a certain frequency, besides, the goods and services market for the buyers is constant, as well;

2. Specificity. The political advertisement operates with the concepts which mostly do not have referents in reality, it urges to "choose" the abstract nonmaterial essences, such as "democratic choice", "national pride", "social justice" etc." (Psikhologiya v reklame, 2007: 175), or the omnipresent "changes for the best" and "best options" while the commercial advertisement is directed towards a specific, obvious and achievable aim, i.e. purchasing the goods by a certain company or a visit to a certain shop;

3. Differentiation. The political advertisement "popularizes just one idea - public order change" (Psikhologiya v reklame, 2007: 175), while the commercial one is very diverse in this aspect, since it is designed to satisfy different needs of buyers, and represent a vast variety of goods, which is much wider than the one offered in the political ads;

4. Audience coverage. Despite the fact that it's still an advertisement, therefore, a massively wide-spread text, the political advertisement is "aimed at a limited contingent - 25-30\% of the voters who do vote" (Psikhologiya v reklame, 2007: 176), while the commercial one covers a much larger part of the population, since "almost everyone has to solve the task of 
choosing and purchasing the goods and services" (Psikhologiya v reklame, 2007: 175), scilicet, "there are much more real buyers than real voters" (Psikhologiya v reklame, 2007: 175). This is especially essential nowadays, when usually, in spite of the economical and social instability, as well as the changes induced by the Covid-2019 limitations, only 10-25\% of Ukrainians actually visit the elections and take their time to cast their votes.

The certain temporal limitation of the political advertisement slogan motivates its far more concentrated suggestivity (comparing to the commercial one), since it has to affect the recipient during a shorter period of time, and thus, has to contain more potentially suggestive elements in order to influence the audience.

\section{Special traits of a political slogan}

It should also be noted that political advertising slogans are mostly created by the representatives of the mentality of the country where the elections take place, and created exclusively for the voters who represent the same mentality, so it's obvious that it is necessary to take into account the chosen linguistic mentality when constructing a slogan, since every "reality is described by means of the national language" (Kozlovska, Tereshchenko, 2019: 47). As of now, commercials of the large American and European companies are created without taking into account these characteristics, by translating or imitating the original advertising campaigns, which sometimes slightly or even dramatically lowers their chances of actually influencing the recipients, especially if the mental properties of the two nations differ too much (i. e. Ukrainians and Americans), even though, even for that kind of translation "it is necessary to have a fundamental mastery of different translation strategies for different types of texts, that is, the translator must be a master of translation" (Tsvetaeva, Prishchepa, 2020: 104). A political slogan might be part of a larger text of an advertising campaign, but much more often it is "a separate, complete text, which, in part, may acquire the status of a precedent and become one of the genres of political aphorisms" (Shejgal, 2004: 257). However, the slogan must be correlated with every other part of the political advertising campaign, so that in general it is a coherent complex. Thus, T. Peters emphasizes that the main requirement for the success of a political slogan is "its consistency regarding the key provisions of the candidate's advertising campaign as a whole and consistency with the texts of his interviews, speeches and other promotional materials" (Peters, 1994: 110).

\section{Influential properties of a political slogan}

Well-known researcher of communicative aspects of NLP and Suggestive Linguistics T.Yu. Kovalevskaya singles out the following linguistic characteristics of political texts:

- utilizing the words with diffuse semantics and a minimum of specificity in political speech;

- destruction of subjective dynamics and reference identification;

- stylistic ambivalence revealed in the contextual collision of colloquial elements and terminological borrowings;

- adjustment of established semantic blocks through reframing of discourse, "which in most cases is the result of not a well-thought-out verbal program, which should focus on correct modeling of mass consciousness, but rather inattention, underestimation of language capabilities by political elite, leading to inadequate decoding of their information and their informational marginalization" (Kovalevska, 2001: 233). 
The author emphasizes that "it is desirable to bring political contexts closer to the current level of individual perception through appropriate construction, through which people would perceive this discourse not as virtual parallels, but as a natural element of their existence in the world and society" (Kovalevska, 2001: 233). It follows from the above that the ideal text construct should contain certain components, "where the prerequisite for adequate decoding and appropriate direction of the internal guidelines of the recipients are the specificity, imagery and euphemism of the keywords of the message" (Kovalevska, 2001: 228). But in addition, when compiling political texts it is necessary to take into account "various situational conditions of the functioning of messages" (Dobrovich, 1996: 62) and neutralize "the possible negative factors that may offset the projected perception of current contexts" (Dobrovich, 1996: 62).

\section{Conclusions}

Thus, the modern information environment requires maximum efficiency of the media, in the paradigm of which advertising is one of the most powerful elements. In turn, the focus of the advertising message always lies within the advertising slogan, inherent suggestiveness being its immanent functional feature, the maximum activity of which requires political discourse in view of its target strategies and tactics. Paying more attention to the aforementioned specific traits of political slogans and taking them into account while constructing the political campaign around them would allow not only to carry out the systematization of the available diversity of the political slogans in particular and political advertisement as a whole as the modern informational space's extremely powerful phenomena, but also to optimize the political advertisement sphere as a whole, thus greatly increasing its influential effect.

\section{References}

Cherepanova, Irina (2002). Zagovor naroda. Kak sozdat' sil'nyj politicheskij tekst [Conspiracy of the people. How to create a strong political text]. Moscow: KSP+. [in Russian].

Dobrovich, A. (1996) Obshhenie: nauka i iskusstvo [Communication: Science and Art] Moscow: AOZT “Jauza” [in Russian].

Feofanov, Oleg (2003). Reklama: Novye tehnologii v Rossii [Advertising: New technologies in Russia]. SPb.: Piter [in Russian].

Kovalevska T. Yu. (2001). Komunikatyvni aspekty neirolinhvistychnoho prohramuvannia : Monohrafiia [Communicative aspects of neurolinguistic programming: Monograph]. Odessa: Astroprint. 344 p. [in Ukrainian].

Kozlovska, Larysa \& Tereshchenko Svitlana (2019). Lingual Technologies of Naming in Ukraine. Scientific Journal of Polonia University. Vol 34 (3). Czestochowa: "Educator" Publishing House of Polonia University. Pp. 47 - 55. [in English] DOI: http://dx.doi.org/10.23856/3405. Morozova, Irina (1996). Slagaja slogany [Composing slogans]. Moskva: RIP-Holding. [in Russian].

Ozhevan, N. (nd) Jazyk politiki i jazykovaja politika: posttotalitarnye problemy preodolenija jetnojazykocentrizma [Language of Politics and Language Policy: Post-totalitarian Problems of Overcoming Ethno-linguocentrism]

[Electronic resource]. Retrieved from http://www/niurr.gov.ua. [in Russian].

Peters, T. W. (1994) Political Campaign Advertising. The practice of Political Communication. Englewood Cliffs, N.J.: Prentice Hall. Pp. 100 - 116. [in English]. 
Pocheptsov, Georgij (2001). Teorija kommunikacii [Communication theory]. Moskva: "Refl-Buk". [in Russian].

Psikhologiya v reklame/Pod red. Kandidata psikhologicheskikh naukP.K. Vlasova /2-e izdanie, dopolnennoe, pererabotannoe, ispravlennoe (2007) [Psychology in Advertising / Ed. by PhD in Psychology P.K. Vlasova / 2nd edition, supplemented, revised, revised. Khar'kov: Izd-vo Gumanitarnyy tsentr. 320 p. [in Russian].

Shejgal, E. I. (2004) Semiotika politicheskogo diskursa [Semiotics of Political Discourse]. Moscow: ITDGK “Gnozis” [in Russian].

Shamsollahi, A., Amirshahi, M., Ghaffari, F. (2017). Brand name recall: A study of the effects of word types, processing, and involvement levels. Journal of Marketing Communications, 23 (3), Pp. 240 - 259. DOI: 10.1080/13527266.2014.930068. [in English].

Tsvetaeva, Olena \& Prishchepa, Tetiana (2020). Sports Idioms in Everyday Social and Political Language. Scientific Journal of Polonia University. Vol 38 (1). Czestochowa: "Educator" Publishing House of Polonia University. Pp. 102 - 109. [in English] DOI: https://doi.org/10.23856/3854.

Tepla, O. (2012). Linguistic conception of commercial nomination coining. Bulletin of Alfred Nobel University. Series: Philology, 1(3), 192 - 195. [in Ukrainian].

Yassin, Mohamed Ali Abdel (2020). Factors of a Healthy Way of Life of Ukrainian Schoolchildren in Institution of General Secondary Education. Scientific Journal of Polonia University. Vol 38 (1). Czestochowa: "Educator" Publishing House of Polonia University. Pp. $117-126$. [in English] DOI: https://doi.org/10.23856/3856 